\title{
Kinetics and intrapulmonary disposition of tilmicosin after single and repeated oral bolus administrations to rabbits
}

\author{
G. Gallina • L. Lucatello • I. Drigo • M. Cocchi • \\ S. Scandurra • F. Agnoletti • C. Montesissa
}

Published online: 18 May 2010

(C) Springer Science+Business Media B.V. 2010

\begin{abstract}
Tilmicosin (TIM, Pulmotil ${ }^{\circledR}$ ) was administered to eight rabbits by oral gavage at a dose of $12.5 \mathrm{mg} / \mathrm{kg}$ body weight for 2, 5, and 7 days, and its plasma kinetics and intrapulmonary disposition were investigated. TIM concentrations in plasma samples collected after days 1 and 6 of treatment were measured by high-performance liquid chromatography with ultraviolet detection. The pharmacokinetic parameters, obtained by non-compartmental analysis of TIM plasma concentrations, did not show any significant variations between days 1 and 6. From the second day of treatment, TIM concentrations attained in lung tissue and pulmonary alveolar macrophages (PAM) exceeded those in plasma by 7 - and 400-fold, respectively, and high levels were maintained in lung tissues during the entire treatment duration. After the first day of withdrawal, a fast decline in TIM levels in both plasma and lung tissue was observed, but in PAM, much higher concentrations were maintained after 3 days of TIM withdrawal.
\end{abstract}

Keywords Tilmicosin $\cdot$ Kinetics $\cdot$ Alveolar macrophages $\cdot$ Rabbit

\author{
Abbreviations \\ TIM tilmicosin \\ PAM pulmonary alveolar macrophages
}

\section{Introduction}

Tilmicosin (TIM) is a semi-synthetic macrolide antibiotic approved for veterinary use in cattle and swine to treat respiratory disease. TIM is active in vitro against several Gram-

G. Gallina $\cdot$ L. Lucatello $~ C$. Montesissa $(\bowtie)$

Dipartimento di Sanità Pubblica, Patologia Comparata ed Igiene Veterinaria, Viale dell'Università 16, 35020 Legnaro, PD, Italy

e-mail: clara.montesissa@unipd.it

I. Drigo $\cdot$ M. Cocchi $\cdot$ F. Agnoletti

Istituto Zooprofilattico delle Venezie, Treviso, Italy

S. Scandurra

Eli Lilly Italia S.p.A, Sesto Fiorentino, FI, Italy 
negative bacteria that cause respiratory disease, such as Actinobacillus pleuropneumoniae, Pasteurella multocida, Mannhemia haemolityca, and Mycoplasma (Womble et al. 2006). Clinical studies carried out in swine and calves by TIM oral administration have confirmed its good efficacy against pathogen pulmonary bacteria and its ability to modulate the inflammatory process by reducing inflammatory mediators in lung tissue (Scorneaux and Shryock 1998; Chin et al. 1998). TIM can easily accumulate in pulmonary alveolar macrophages (PAM) because of the ion-trapping process (Honeybourne 1997). Indeed, the great $\mathrm{pH}$ difference between the intracellular compartment and plasma allows TIM to attain higher concentrations in PAM than in plasma. To study TIM disposition in rabbits, its plasma kinetics, and its distribution in lung tissue, PAM were evaluated after one single or repeated oral administration of the drug at $12.5 \mathrm{mg} / \mathrm{kg}$ b.w. for 7 days to healthy rabbits.

\section{Materials and methods}

Twenty female New Zealand White rabbits (mean weight $4.2 \pm 0.4 \mathrm{~kg}$ ) were purchased from Charles River (Calco, LC, Italy), housed in single cages at the facilities of the Istituto Zooprofilattico Sperimentale delle Venezie (IZSVe), and cared for in accordance with the IZSVe Standard Operating Procedures. The experiments received the approval of the local ethics committee. After 7 days of acclimatization, the animals were randomly divided into five groups of four rabbits each, and tilmicosin (Pulmotil ${ }^{\circledR}$ ) was administered by oral bolus at $12.5 \mathrm{mg} / \mathrm{kg} \mathrm{b.w.} \mathrm{once} \mathrm{a} \mathrm{day} \mathrm{in} \mathrm{the} \mathrm{early} \mathrm{morning} \mathrm{for} 2$ days (group 1), 5 days (group 2), and 7 days (groups 3, 4, and 5).

To study TIM plasma kinetics, rabbits from groups 4 and 5 were used. On the first and sixth day of treatment, blood samples $(1 \mathrm{~mL})$ were collected from the marginal ear vein of each rabbit at 15 and $30 \mathrm{~min}$ and at $1,2,4,8,10$, and $24 \mathrm{~h}$ after administration. Blood samples were collected into heparinized tubes, centrifuged at $1,500 \mathrm{rpm}$ for $10 \mathrm{~min}$ to obtain plasma samples, and stored at $-80^{\circ} \mathrm{C}$ until analysis.

To investigate the pulmonary disposition of TIM, groups 1, 2, and 3 were euthanized by $\mathrm{CO}_{2}$ overexposure in a $\mathrm{CO}_{2}$ cabinet, $2 \mathrm{~h}$ after the last dose, respectively, on days 1,5 , and 7 of treatment. Lungs were removed from the thoracic cavity, and a bronchoalveolar lavage (BAL) was performed to collect PAM by injecting $30 \mathrm{~mL}$ of $37^{\circ} \mathrm{C}$ Dulbecco's phosphatebuffered saline (D-PBS) into the trachea. After a 10-min lung gentle massage, the fluid suspension was recollected and the first $5 \mathrm{~mL}$ were discharged. The procedure was repeated twice, and the two suspensions were pooled and centrifuged for $20 \mathrm{~min}$ at $1,500 \mathrm{rpm}$, to collect cells. The cell pellet was suspended in D-PBS to a final cell concentration of $1 \times 10^{6}$ cells $/ \mathrm{mL}$. Lung samples and PAM were stored at $-80^{\circ} \mathrm{C}$ pending the analysis.

The rabbits from groups 4 and 5 were euthanized after the end of the treatment on the first and the third days of drug withdrawal, respectively, to check for TIM persistence; lung tissues and PAM were collected as described above.

Qualitative and quantitative determinations of TIM were performed after drug extraction from matrices with methanol and PBS at $\mathrm{pH} 2.5$ and purification by solid-phase extraction (cartridges Strata-X, Phenomenex). Drug concentrations were measured by an HPLC method (column Zorbax Eclipse Plus C18, flow $1 \mathrm{~mL} / \mathrm{min}$ ) with UV detection at $287 \mathrm{~nm}$. Pharmacokinetic analysis of drug concentrations at different sampling times was performed for each animal using the computer software Win NonLin Prof 5.0.1 (Pharsight Corporation, USA), while statistical analyses of pharmacokinetic parameters were performed using the computer software Prism 4.02 (GraphPad Software Inc., USA). 
Table 1 Mean pharmacokinetic parameters of TIM $( \pm$ SD) obtained from to eight rabbits after a single (A) and repeated (B) oral administration at a daily dose of $12.5 \mathrm{mg} / \mathrm{kg}$

(A)

\begin{tabular}{|c|c|c|c|c|c|c|c|}
\hline \multirow[b]{2}{*}{ Variable } & \multicolumn{3}{|c|}{ 1th day } & \multirow[b]{2}{*}{ Variable } & \multicolumn{3}{|c|}{ 6th day } \\
\hline & $X_{m}$ & $\mathrm{SD}$ & $\mathrm{Me}$ & & $\mathrm{X}_{\mathrm{m}}$ & SD & $\mathrm{Me}$ \\
\hline $\mathrm{C}_{\max }(\mu \mathrm{g} / \mathrm{mL})$ & 1.31 & 0.65 & 1.12 & $\mathrm{C}_{\max }(\mu \mathrm{g} / \mathrm{mL})$ & 1.30 & 0.63 & 1.18 \\
\hline $\mathrm{T}_{\max }(\mathrm{h})$ & 0.66 & 0.30 & 0.50 & $\mathrm{~T}_{\max }(\mathrm{h})$ & 0.56 & 0.29 & 0.50 \\
\hline $\operatorname{AUC}_{0-\infty}\left(\mathrm{h}^{*} \mu \mathrm{g} / \mathrm{mL}\right)$ & 3.59 & 0.63 & 3.68 & $\mathrm{AUC}_{0-\infty}\left(\mathrm{h}^{*} \mu \mathrm{g} / \mathrm{mL}\right)$ & 3.31 & 0.63 & 3.32 \\
\hline MRT (h) & 5.29 & 1.35 & 5.15 & MRT (h) & 6.85 & 3.09 & 5.36 \\
\hline $\mathrm{t}_{1 / 2}{ }^{\mathrm{a}}(\mathrm{h})$ & 2.60 & 0.77 & range & $\mathrm{t}_{1 / 2}{ }^{\mathrm{a}}(\mathrm{h})$ & 4.31 & 1.65 & range \\
\hline
\end{tabular}

$\mathrm{X}_{\mathrm{m}}=$ arithmetic mean; $\mathrm{SD}=$ standard deviation; $\mathrm{Me}=$ median

${ }^{\text {a }}$ Harmonic mean

\section{Results}

The results obtained demonstrate that the oral administration of TIM at $12.5 \mathrm{mg} / \mathrm{Kg}$ b.w. to rabbits attained the highest plasma concentration $\left(\mathrm{C}_{\max }\right.$, range $\left.0.5-2.4 \mu \mathrm{g} / \mathrm{mL}\right)$ within 30 min (range 15-60 min). During the first day of administration, the mean plasma concentrations declined to values lower than $0.5 \mu \mathrm{g} / \mathrm{mL}$ within $4 \mathrm{~h}$. Plasma concentrations measured on day 6 of repeated treatment overlapped those recorded on the first day. The main kinetic parameters (Table 1) were obtained by non-compartmental analysis of plasma concentrations from animals treated with TIM on the first day; by the sixth day, these parameters were not significantly different (Table 1 ).

TIM concentrations in lung tissues of animals euthanized $2 \mathrm{~h}$ after the second and fifth days of treatment, exceeded those in plasma 5-fold and 8-fold, respectively. TIM concentrations in alveolar macrophages exceeded those in plasma by 300-400 fold. At variance, plasma concentrations did not change significantly after repeat TIM dosing (Table 2).

\section{Discussion}

The results were consistent with data obtained in a previous preliminary study in rabbits (Fedrizzi et al. 2008). TIM concentration in lungs and in PAM from all animals exceeded

Table 2 Mean TIM concentrations ( \pm SD) in plasma, lung tissue, and PAM after 2, 5, and 7 days of treatment (d) and 1 and 3 days after drug withdrawal (w)

\begin{tabular}{|c|c|c|c|c|c|c|}
\hline \multirow[t]{3}{*}{ days } & \multirow{2}{*}{\multicolumn{2}{|c|}{$\frac{\text { PLASMA }}{\mu \mathrm{g} / \mathrm{mL}}$}} & \multirow{2}{*}{\multicolumn{2}{|c|}{$\begin{array}{l}\text { LUNG } \\
\mu \mathrm{g} / \mathrm{mg}\end{array}$}} & \multirow{2}{*}{\multicolumn{2}{|c|}{$\frac{\text { PAM }}{\mu \mathrm{g} / \mathrm{mL}}$}} \\
\hline & & & & & & \\
\hline & mean & SD & mean & SD & mean & $\mathrm{SD}$ \\
\hline d 2 & 0.25 & 0.03 & 1.29 & 0.47 & 93.87 & 32.33 \\
\hline d 5 & 0.40 & 0.09 & 2.69 & 0.73 & 147.02 & 77.02 \\
\hline d 7 & 0.27 & 0.03 & 2.18 & 0.81 & 115.17 & 69.59 \\
\hline w 1 & 0.05 & 0.04 & 0.73 & 0.14 & 136.58 & 62.21 \\
\hline w 3 & 0.09 & 0.08 & 0.15 & 0.09 & 43.88 & 12.97 \\
\hline
\end{tabular}


those in plasma at all sampling times, confirming that TIM can accumulate in tissues during treatment.

Preliminary data confirm that in the epithelial lining fluid (ELF), TIM can attain concentrations 5- to 10-fold higher than in plasma. The results obtained here confirmed the apparent correlation between repeated TIM oral administration at $12.5 \mathrm{mg} / \mathrm{kg}$ and the increase in intrapulmonary concentrations.

As reported for other drugs (Groll et al. 2006), TIM kinetic behaviour suggested that lung tissue and alveolar macrophage concentrations may be more relevant than plasma concentrations to correlate antibacterial efficacy when PK/PD models are adopted for the evaluation of schedule dosage. Despite the bioavailability and efficacy of macrolide molecules sequestered in the intracellular compartment of PAM as discussed by Toutain (Toutain et al. 2002), according to McKellar (McKellar et al. 2004), the release of drug from intracellular sites during phagocytosis can help to maintain sustained tissue concentrations and subject bacteria to prolonged exposure appropriate for a timedependent drug.

\section{References}

Chin AC, Morck DW, Merrill JK, Ceri H, Olson ME, Read RR, Dick P, Buret AG (1998) Anti-inflammatory benefits of tilmicosin in calves with Pasteurella haemolytica-infected lungs. Am J Vet Res 59:765-771.

Fedrizzi G, Accurso D, Scandurra S, Montesissa C (2008) Kinetic of tilmicosin after per os administration to rabbits. Proceedings of 4th AAVM Conference, Prague

Groll AH, Lyman CA, Petraitis V, Petraitiene R, Armstrong D, Mickiene D, Alfaro RM, Schaufele RL, Sein T, Bacher J, Walsh TJ (2006) Compartmentalized intrapulmonary pharmacokinetics of amphotericin B and its lipid formulations. Antimicrob Agents Chemother 50:3418-3423

Honeybourne D (1997) Antibiotic penetration in the respiratory tract and implications for the selection of antimicrobial therapy. Curr Opin Pulm Med 3:170-174

McKellar QA, Sanchez Bruni SF, Jones DG (2004) Pharmacokinetic/pharmacodynamic relationships of antimicrobials drugs used in veterinary medicine. J Vet Pharmacol Ther 27:503-514

Scorneaux B, Shryock TR (1998) Intracellular accumulation, subcellular distribution and efflux of tilmicosin in swine phagocytes. J Vet Pharmacol Ther 21:257-268.

Toutain PL, Del Castillo JRE, Bousquet-Mélou A (2002) The pharmacokinetic-pharmacodynamic approach to a rational dosage regimen for antibiotics. Res Vet Sci 73:105-114

Womble A, Giguère S, Murthy YVSN, Cox C, Obare E (2006) Pulmonary disposition of tilmicosin in foals and in vitro activity against Rhodococcus equi and other common equine bacterial pathogens. J Vet Pharmacol Ther 29:561-568. 